\title{
The Independent Reefer Operators from Material, Discursive, and Subjective Perspectives
} \\ The Interwar Period: the Birth of the First Independent Reefer \\ Operators
}

The companies active before the Second World War, which we have covered in the book are banana companies such as United Fruit, meat conglomerates such as the Vesteys, including Blue Star Line, and third party shipping companies specializing in reefer cargo such as Lauritzen and Salén. The banana companies had reefer fleets, but these were entirely dedicated to carrying the respective company's cargo - they were in-house logistics departments. Blue Star Line operated reefers, but these were either catering to the Vestey group's internal needs for meat (and dairy) transport or as a complement to Blue Star's established general cargo lines.

What could be called the independent reefer industry was, before the Second World War, very limited. Sven Salén shipped United Fruit's bananas from the Continent to the Northern countries as a third-party shipping company. His company also offered inland transport for bananas, and other fruit. In this period there were still significant challenges for the transport of bananas, and much of the system built up by Salén and Matthiessen tried to solve this transport problem. Salén was an entrepreneur with ambition, an entrepreneur who was not content with being just a link in the logistical chain of United Fruit. In the end of the 1930s, we know that it took the step to order its first purpose built reefer ship in order to start carrying bananas across the Atlantic. The company wanted more.

Lauritzen developed differently than Saléns. Rather than taking the leap from transporting general cargo to transporting bananas as did Saléns, Lauritzen gradually moved into the segment. Given its dry cargo tramping business, it had carried fruit at times, but in the 1920s, it made a calculated decision to avoid tramping. To move its focus towards the fruit trades in the Mediterranean was seen as a good, rational choice, headed by the young generation of Lauritzen. Lauritzen's cargo, for example citrus, was less problematic than bananas and was more common in the Northern countries. One could therefore carefully suggest that forces of logos were dominant in the earliest period of Lauritzen's fruit shipping. Lauritzen originally had an ambiguous relationship 
with the established shipping conferences. Sometimes it participated in them and at other times they were outsiders snapping up cargoes as the opportunities arose.

Soon, however, Lauritzen started to see fruit shipping as one of its core businesses. Given its good reputation as a fruit carrier, Lauritzen was asked to carry bananas long-distance in the 1930s. The first cargo was carried with conventional ventilated fruit carriers, and Lauritzen took considerable pride in managing to successfully transport the cargo from West Africa to France. The banana was, in the 1930s (and onwards), the symbol of reefer shipping excellence. In the 1930s, Lauritzen gained contacts worldwide to transport fruit, including bananas, thereby being in stark contrast with Salén's reefer part which was basically a one-trade business. Part of the desires of Lauritzen, and more especially Ditlev Lauritzen, was to always have a modern fleet, which led to considerable fleet renewal, and many newbuildings of reefers. The thymos of Lauritzen was plausibly related to its quite newly established reputation as a high-quality shipping company, able to carry any kind of fruit including the banana, as well as a shipping company with a very modern fleet.

Materially, the two companies were different. At this time, Salén was still operating its Nordic feeder service with ventilated fruit carriers. The rapid expansion of Lauritzen in contrast with Salén was most probably due to Lauritzen's wider scope of fruit carried, more varied trades, as well as the fact that the company was large, compared to Saléns, and had more resources for new ventures. Not the least was the aggressive fleet renewal policy important. Lauritzen had taken delivery of about eight reefers when Salén's built its first one. It is obvious that Lauritzen was the first company which could really qualify as an independent reefer operator. Carrying reefer cargo was its core business, it had considerable independence from its customers, and it was not owned by a shipper. Lauritzen's banana customers were also smaller players with less, if any, shipping of their own. This may have stimulated Lauritzen's development as a genuinely independent operation. Salén on the other hand were a link in market-leading United Fruit's logistical chain. Shifting our perspective to the general reefer industry, but still taking a material perspective, we know that its history goes back to the late 19th century. Therefore, both Salén and Lauritzen were new, small players compared to the liner companies which shipped significant amounts of refrigerated and frozen cargoes both carried in part-reefers and in dedicated reefers complementing their liner operations. And likewise small compared to the shippers, for example United Fruit's own reefer fleets. The phenomenon of independent reefer operators therefore started as a very marginal phenomenon. 
Regarding the discourses on the level of the general reefer industry, we would like to pay attention to that about the banana. Already since the end of the 19th century, as has been described in chapter 2, there was a quality discourse around the banana, more so than regarding other fruit: It was of utmost importance that the banana arrived to the markets in a good condition. The banana was, and still is, the most sensitive major reefer cargo within the categories of fruit, fish, and meat. Many stories about early specialized reefer shipping were about spoiled bananas arriving at the docks. In other words, the discourses about the sensitivity and perishability of the banana, coupled with the need to deliver bananas in pristine condition provided the discursive background to the subjective forces discussed above. Both Salén and Lauritzen derived pride from being able to carry the banana and the quality discourse trickled into the two companies.

The birth of independent reefer operators mostly stems from the material realities of trans-Atlantic and other long-distance fruit trade. For this purpose, reefer ships were needed. The banana had a particular status amongst the fruit discursively and it was not even seen as a fruit but as a separate cargo category. To be able to carry bananas successfully was a source of pride for the independent reefer operators. The meat trades were often catered for by shippers or by general liners and did not spur the creation of independent reefer operators. At this stage in history, there was no collective, subjective sensemaking amongst for example Salén and Lauritzen to be part of an independent reefer industry. This would change after the Second World War.

1950s: the Wild Reefers

Salén and Lauritzen were the main independent reefer operators in the decade following the Second World War. Indeed, it is in the 10-15 years after the war in which one could say that an industry of independent reefer operators really is established. The most remarkable post-war development is the growth of Saléns.

A complex set of factors led to Salén establishing itself as the leading independent reefer operator. As we already saw in the preceding section, Sven Salén was interested in growing his reefer business, by importing bananas across the Atlantic. He therefore had a will to expand and grow, an entrepreneurial drive of eros. But much of Salén's growth was due to the strategies of United Fruit. They recognized that Salén was a potential strategic partner, not only on the regional but on the global level. He was a partner who was willing to build the tonnage that United Fruit so desperately needed after the losses 
caused by the war. The material base was reduced during the war, which led to a space for tonnage renewal and innovation. However, Saléns lacked the knowhow to build the most modern reefers. Therefore, United Fruits let Salén gain access to the drawings of their latest reefers in the late forties. This instantly put Saléns at the cutting edge of reefer technology. Newbuildings soon followed, and many of these were built in Sweden that had escaped the war with its industry intact. This established an industrial competence in Sweden which served as a resource base for Saléns for decades. The combination of knowhow from United Fruit with the material production capacity of Swedish shipyards was crucial for Saléns. In other words, Salén's was to a large extent a product of the relationship with United Fruit.

Salén positioned itself as a loyal transport provider to United Fruit, but also realized that they should not rely solely on one customer, and therefore developed side businesses with other fruit, fish, and meat. The material and immaterial resources built up in the banana trade could be leveraged in order to expand into other lucrative refrigerated trades. The side business was Salén's way to enter into the specialized reefer industry, where it, thanks to its numerous newbuildings quickly became the main actor. Lauritzen also expanded during the post-War period buying 43 ships from 1945 to 1958, many of which entered the banana and fruit trades. Lauritzen continued to renew its tonnage constantly, given the reduced material base as well as the desire in the company to always have modern tonnage.

Now, these two independent reefer operators started to interact more with the general reefer industry. Both companies broke into the trades that had traditionally been carried by liner conferences. Saléns and Lauritzen could offer more dedicated transports at a good price which suited the exporters and importers of perishables. The combined capacity of the two companies now led fruit exporters to consider the specialized reefers as a viable alternative to liner conferences. In the minds of the customers, the independent reefer industry was established. As we discussed in the introduction, the subjective perceptions of actors are of high importance for what happens in an industry. The birth of the specialized reefer industry is based on this shift of perception from being a set of material artefacts (reefers) which were often tied up in established patterns of trade, the operators had managed to create the perception that there was an independent reefer industry, with several actors such as Salén and Lauritzen but also others like Gustaf Erikson based in Finland.

The whole reefer industry was a small challenger to the established liner companies and saw themselves as being wild, in contrast to the traditional, outdated, and even boring, liner companies. As far as into the 1970s, the inde- 
pendent reefer industry, the part which was not tied up into stable flows of products, such as bananas, was called "wild reefers".

Materially, the companies grew because of the rising demand for the transport of refrigerated products. Part of this growth was absorbed by liner companies, but there were niches which independent reefer operators were quick to fill. The banana companies needed to build up their fleets after the Second World War and used third-party players, such as Salén and Lauritzen. The same discourses reigned over the general reefer industry - the discourse of banana quality. The demands of the banana companies for constantly better transports led to quality improvements at Salén and Lauritzen, who now were in charge of technological development. The large number of newbuildings in combination with the discourse of quality led to incremental changes being incorporated into the ships. Also, the ships became faster which was represented both materially and discursively. The specialized reefer industry saw and talked about themselves as being able to deliver goods to the market more quickly than liner companies, due to fast ships and more direct trading patterns. It is plausible that with the increasing speeds, the discourses about "banana destroyers" - fast, dedicated ships were born here. Yet another material and discursive element which emerged was size. The specialized reefer companies promoted their large refrigerated capacity. So even though they were relatively small vessels, the fact that they were fully refrigerated meant that they could take larger refrigerated cargoes than most liner vessels. Furthermore, liner vessels were tied up in regular trading arrangements, so additional capacity available at any one time was more limited. In contrast, the wild reefer, raced to its destination, frequently in ballast, and could fill the entire ship with the customer's cargo. This was particularly well suited to seasonal trades which was something that kicked-off during the wild reefer era. So the wild reefers were positioned to be able to take large one-off cargoes which is a different style of business than the industrial shipping carried out by both the liner companies and the regular shipments of the major banana companies.

All of the above led to the discourse of the wild reefer, which in a sense is the discourse of the new, small, aggressive competitor, in contrast to old-fashioned liner companies. A fight between David and Goliath. The upstarts were driven by eros, by a will to win and they were thrilled at the prospect of taking on the big guys. They were proud to be the underdog that chipped away at the liners' fruit trades. And Goliath hardly noticed that David was even there.

To sum up this decade, it was the birth of the discourse about the independent reefer industry - consisting of several operators. They were all talked about as fast, large, and wild. All of these discourses were framed in opposition to the characteristics of the prevailing, dominant transport mode - the 
conference lines. The banana companies were still important actors, as they spurred technological development, related to the quality discourse, which led independent reefer operators to constantly renew tonnage, which led to a large base of somewhat older ships suitable for the transport of other fruit, fish, and meat. Subjectively, although there was competition between the independent operators, much of the eros concerned the thrill of breaking into new trades, usually at the liner companies' expense.

\section{1960s: Rationalizations and Explosive Growth}

The 196os were marked by different forms of rationalisation with some degree of incompatibility: boxes, pallets, and containers.

Panama Disease led the banana companies to switch to the resistant but otherwise more fragile Cavendish variety which resulted in the bananas being placed in boxes instead of being shipped in bunches. The problems concerning the banana led to lower profitability, causing banana companies to outsource their capital-intensive fleets. In the late 1960s, Sunkist, which increasingly became a major partner of Salén, wanted to export their produce on pallets as a way to rationalize the handling of cargo. Last but not least, containerization swept through the shipping industry. Container technology for refrigerated products were introduced on a number of lines, but given the cost and difficulties of containerization, liner companies left the refrigerated trades. The replacement of liner tonnage with non-refrigerated container ships caused an important supply shortfall that the independent reefer operators were quick to exploit.

These material changes led to the growth of the independent reefer operators. They were the takers of the outsourced fleets of the banana companies and they could also fill the market gaps left by liner companies which left due to containerization. Although demand of seaborne refrigerated transport grew modestly, Salén's grew explosively and had in the end of the 1960s a fleet of over 100 ships. Lauritzen was significantly smaller, but also grew during the period. Hamburg Süd grew as an independent player with a fleet of about 20 reefers.

This once again led to a change in the subjective perception in and of the specialized reefer industry. They were no longer a wild, eros-driven, alternative to the liner companies, but increasingly became the way to transport refrigerated cargo. They were now of such a large size that they could more adequately be seen as (equal) partners to their customers, rather than their servants. This led to strong sensations of pride across the whole industry, which was one 
way how thymos was represented during the period. Within the industry, the players had different positions. Salén's had become the market leader and prided themselves on their rationalised transport systems and advanced scheduling, including computerized scheduling. They did not just see themselves as the market leader, but as the uncontested market leader, since Lauritzen was less than half the size of Salén. Lauritzen, on the other hand, still saw themselves as a hungry competitor, remembered as "shark's teeth" by one of our sources.

Discourses of large capacity and speed were still prevalent, but to this we must add the increasing sophistication and flexibility of the new ships that were developed, and this had consequences for the specialized reefer industry. Since the players in the specialized reefer industry were no longer a wild alternative, but increasingly became established specialists, able to offer sophisticated services to its customers, Logos entered the stage to a larger extent than previously. Logos meant that the specialized reefer industry should be able to fulfil the customers' expectations to be able to provide low-risk, industrial shipping. And we know that each customer was rationalizing its cargo handling in slightly different ways. This resulted in ship designs that could cater for different cargoes with different requirements. Examples of such flexible ships were the Snow series and the Italian Reefer class, which could handle pallets as well as boxes. Still during this period, the container technology was not incorporated into specialized reefers. In the specialized reefer industry, there was a growing perception that it was the pallet that was going to be the preferred way of handling refrigerated cargo.

1970s: the Others

In the late 196os, Salén was the largest company followed by significantly smaller Lauritzen and Blue Star Line and even though there was competition between them, there was a degree of understanding about the rules of the game. Salén would keep its dominance throughout the decade, while Lauritzen joined forces with $\mathrm{P} \& \mathrm{O}$ to create LPR. The fruit trades were widely perceived as lucrative by the independent reefer operators. Blue Star, for example, expanded its presence in the fruit trades by building the modern A-class in the mid-1970s.

Salén became more professionalized during the 1970 and divisional managers, for example the managers of the reefer division, became more powerful. The trend of rationalization that was started in the 196os, continued into the 1970s. During this decade, independent reefer operators became convinced 
that the pallet was the natural way to unitize refrigerated cargo. They followed the trend of containerization, which was growing, but still thought that the pallet would be preferred amongst customers. Both Salén and LPR worked on optimizing pallet handling. A ship type that was optimized for pallet handling was the Winter class. Despite considerable continuity from the 1960s, the competitive situation amongst the independent reefer operators would change because of some new entrants. The 196os had spurred the interest of companies looking for attractive business opportunities within the reefer segment.

A first entrant was the Israeli company MFC. It represented the first largescale speculative reefer investment in the history of the industry. MFC controlled about 40 reefers, which was about half the size of Salén's fleet, and basically built them to force Salén to charter them. Salén was provoked by this entry which is highly visible in its discourses. MFC was called unknowledgeable, financial, and speculative. Salén claimed that MFC had no understanding of the reefer market, or otherwise they would not have built so many reefers. For a short while, MFC's market entry was successful as they managed to charter their fleet to Saléns and thereby secure income. But for our purpose, this shock to the industry make us understand that there was more or less a controlled situation in the industry before the entry of MFC.

Then, there were the Japanese entrants, such as the fishing companies and NYK. The Japanese entrants were seen by the incumbent companies, in our empirical material mostly from the perspective of Salén, as a radical other. The entry of the Japanese cast a light on the racial constitution of the industry. All reefer companies were controlled by caucasian male managers and employees, who all were internationally minded and of course spoke English. With the entry of the Japanese, there were a new breed of competitors, where possibly only one or a few persons in the organization could speak English. That they further were critiqued for being too competitive and offering too low rates only contributed to this othering.

A third entrant at this stage was Seatrade. It had started out with a single reefer in 1962, but grew towards bigger and more ships. In contrast to Salén and Lauritzen, its main business was fish transport. From the perspective of the incumbent specialized reefer operators, Seatrade was a non-issue because they did not have many ships, the ships were small and therefore of a different kind than the ships that really mattered - the big fruit carriers, and also they were focused on fish, which both Salén and LPR only engaged with as a non-core business. From Seatrade's perspective, the competitors were not really Salén and Lauritzen. A representative of Seatrade even remembers Salén giving away a trade to Seatrade, since Salén was not interested in it. They were indeed in a different segment, but Seatrade knew that it was more profitable to move 
towards larger ships, due to economies of scale. For the moment, the point was just to pragmatically employ the ships as well as possible. The company was doing deals as they appeared and to some extent seemed to lack a strategy. It did not thymotically pride itself by carrying a certain cargo type, like the banana, but similarly to Salén and Lauritzen they took pride in optimizing trade patterns, for example their great Atlantic Circle. They also prided themselves thymotically for being very hands-on and frequently referred to their history of stemming from a group of captain-owners. This stands in contrast to the academic culture that reigned at Salén, where people with good education was sought for. The company was therefore, in contrast to LPR and Saléns, much more engaged in S\&P activities, quickly responding to new opportunities in the market.

The 1970s was the decade of the oil crises and significantly increased bunker costs. The transport cost therefore increased, particularly for ships that had high bunker consumption. This is likely to have favoured new players, such as Seatrade, which could build a business without having to manage a fleet of ships with high fuel consumption. Also, smaller reefers turned out to be even less economically viable than earlier due to lack of economies of scale. But while the smallest ships became bigger, the increases of reefer ship sizes in the largest category also ceased. In all, this led to a situation in the end of the 1970s, where the discourses of "faster" and "bigger" to some extent declined. The Winter class was slightly smaller than the Snow class and also slower. The reefer industry was at a turning point, both due to oversupply of tonnage and due to increased fuel costs. Due to the increased transport costs, banana companies took back part of their fleet into own control, which further increased the number of active players within the industry. Competition therefore went up and the rates were often low due to the oversupply of tonnage. These material conditions can also have impacted on the view of the incumbents on the new entrants, in a sense blaming them for the low market. One could almost say that there is a perception of harmonious competition that changed towards a fierce competition between many new actors that were unknown to each other, such as the Japanese companies, Seatrade, and Laskaridis.

The early 1980 s caused problems for the two major independent operators, Salén and Lauritzen, who was now again a lone-standing organization after P\&O's exit from the reefer segment. Mainly due to problems in other parts of the Salén conglomerate, Salén went into bankruptcy in 1984. As we know, this 
was led by a collective effort to rebuild a new organization. This was not just a process of logical reasoning - that there was a space in the market for a revived operator, but very much a process based on eros and thymos. The former employees all wanted to work for this new organization, not only to secure a new job, but to build something new. To make sense of their actions, they used discourses from war and struggle, describing the office as a command center. When the new company was setup, they were all very proud and happy about the outcome, until the employees realized that they were not part-owners but mere employees. Some of the energy in the organization was lost already there and in the subsequent ownership struggles. But when the market went up, and with a new owner, the organization was once again filled with drives to grow. The people working in Cool Carriers had a strong thymotic feeling of being autonomous - as an organization that was resilient to ownership changes. Cool Carriers' thymos was also linked to its stunning come-back to market leadership, its self-perception of superior expertise, and its perceived control over business partners.

Lauritzen suffered similarly in the early 1980 . It was not hit by a bankruptcy but instead by a report that basically said that the reefer division should be dismantled fully or partly. This was seen as outrageous from the reefer division and also upper management. This gives a sense of what an important part the reefer division was to Lauritzen psychologically. While Lauritzen struggled with red numbers, it adopted the most rational, logos-oriented, way of conducting business - namely to develop a ship type that was fuel-efficient, rational, and which completely abandoned all previous aesthetic ideals of reefer ships - the Jumbo class. To gradually divest non-economic tonnage and invest in more Jumbo ships was seen as the way forward. But top management interfered and created a prestige ship to be used by the reefer division - the Family vessels. On the one hand, this was purely rational, logos-oriented, from a group perspective since it solved the problem of Lauritzen's shipyards. One the other hand, to develop the biggest and most modern reefer in the market, stemmed from the particular thymos of the Lauritzen spirit: to always choose the highquality solution. This conflicted with the logos-orientation of the reefer division. Not the least since all other actors, including Lauritzen's reefer division, was opting for the simple, slower, inexpensive, and rational. The Family class, although appreciated by some at Lauritzen's reefer division was seen as a blow to the agency of the reefer division. When they had just found a way of rationalizing their tonnage, a new kind of uneconomic ship type was entering its fleet. Still, the good market in the end of the 1980s kept the spirits up at Lauritzen. 
Apart from these two operators, Seatrade, which Saléns and Lauritzen saw as more or less insignificant in the 1970s began to make its presence felt. They started to envision growth and larger ships, which resulted in newbuildings, recruitment of personnel and the acquisition of companies. They became proud of their new, highly optimised and rational ships. Furthermore, Seatrade's thymos was highlighted when they acquired of Dammers \& van der Heide in 1989. Seatrade perceived Dammers to be a traditional, hierarchical, high-shipping company in Rotterdam, in total contrast to the hands-on thymotic spirit at Seatrade.

NYK and other Japanese operators continued to have a significant presence in the market. It is interesting to see how they started in the periphery of independent reefer operators, to gradually move closer to the core. They have told us that it was far less prestigious to carry mutton from New Zealand to the Middle East than the large and lucrative banana trades or the trades from South America. Another example that illustrates the problems for the new entrants was Nissui's desired collaboration with Lauritzen and Cool Carriers, but these plans were rejected. Unsurprisingly, they teamed up with another outsider, Seatrade, on a trade from the Canaries. So, although they had a significant fleet, the Japanese companies felt that they, together with Seatrade, were playing in the second division, below that of Cool Carriers and Lauritzen.

The independent reefer operators increasingly aimed for rational, fuel-efficient ships. The discourse of rationality was contrasted with the sleek ships of the past, which disappeared along with the romantic era of the wild reefers. Perhaps there were some concerns about long-term outlook already in the 1980 s, but the overriding belief at the time was that the next decade would be the golden 1990s, with rates of 100 cents per cubic feet. With efficient and rational tonnage, this would all be possible, wouldn't it? This newbuilding boom was the last collective boom of eros witnessed in the reefer industry.

The container lines had been on the independent reefer operators' radar for decades, but it was during the 1990s when they would enter the reefer industry en masse. Several material changes within the industry led to container lines being able to compete against independent reefer operators. The combination of economic liberalisation and the flexibility afforded by containerization resulted in the fragmentation of the market to the benefit of the container lines. Moreover, the national marketing boards lost their importance as shippers and were replaced by direct contacts between buyers and exporters. The 
concurrent emergence of powerful buyers, such as the major supermarket chains, put pressure on both producers and transport providers. They also contributed to the fragmentation of the producer side by directly encouraging smaller exporters which they in turn could exercise considerable control over. There were therefore more shippers, but with smaller volumes, usually insufficient to fill a specialized reefer. The flexibility and low price offered by the container lines were better suited to this market situation.

Cool Carriers were overexposed when the market weakened in the early 199os, but re-embarked on a cautious growth strategy later in the decade. Cool's organization maintained its autonomy despite several ownership changes and this thymotic feature was still a source of pride. These owners were relatively passive since the owners recognized that Cool surpassed them in competence and market know-how. Rather than adopting the textbook owner governance model, that owners control the organization, the discourses at Cool Carriers were that "if we don't like the owner, we find a new one". This was particularly salient in one episode, when NYK was interested in buying Cool Carriers in 1993. The deal could have materialized was it not for the Cool employees, who stated that if NYK would buy Cool, the employees would leave and start a new competing independent reefer operator. Furthermore, the collective trauma and the overcoming of it in the 1980 s led to a strong group culture at Cool Carriers. When a few key employees left in the 199os to work with Seatrade, this led to much frustration as well as a collective will to take revenge, strike back. This is another manifestation of thymos. Also, this episode shows that, finally, Seatrade was a genuine competitor. The thymos was derived from collective autonomy and was still coupled with the pride of being a high-tech market leader with large modern ships servicing high quality customers. Cool Carriers therefore placed their older and smaller tonnage in separate organizations. This pride and prestige was not only perceived internally. For example, respondents from Eastwind stated that their relationship with Cool Carriers gave them legitimacy and status within the industry. Due to the threat of the container lines, many ship-owners planned to exit and offered to sell their ships. Cool Carriers wanted to continue its fleet expansion, and was able to do this somewhat during Höegh's ownership. Nevertheless, Cool was frustrated at the amount of opportunities that they were not able to pursue because of the limitations imposed by its owners.

Lauritzen, on the other hand, was locked into the same ownership structure as in the 1980 s. The reefer division could not produce adequate results, despite its modern tonnage, and was put under pressure. This led to feelings of impotence and resignation. Some people decided to leave the organization to try new ventures, while others stayed and witnessed the division's decline. The 
management knew that the status quo would lead to a gradual decline and exit, and suggested a bolder move - to consolidate with another operator.

Seatrade, as well as Laskaridis, expanded while other companies were scaling back or exiting the industry. Seatrade grew and constructed, bought and sold vessels, and combined this with a will to maximize returns in the operations, under the leadership of its active owners. A former Seatrade employee told us how the company talked about becoming big, that they wanted to become a reputable player on the global stage, "the grand ballroom". This actually contrasted with the company's prevailing discourses about pragmatism and hands-on owner management. Seatrade were happy to expand into the fruit trades, but much of the enthusiasm manifested in interviews with them was about the sheer quantity of fish delivered.

In contrast to Cool Carriers and Lauritzen, NYK had an expansive newbuilding strategy in the 199os. The management of the reefer division believed in the future of the segment despite containerization and managed to convince the upper management of NYK to invest. Still, compared to other segments at NYK, the money invested in reefers was small. The strategy paid off. NYK secured a prestigious contract with Dole, which was a cause of great pride. It also temporarily broke into Lauritzen's Chile trade, which they described with a strong sense of pride. NYK also was in discussions to acquire Cool Carriers. Salén, which had been role model of NYK Reefer, could now be acquired, which was seen as a source of pride. NYK Reefer's fleet peaked in 1995 when it controlled 57 vessels. They became a reputable independent reefer operator due to both its newfound size, its ability to challenge Lauritzen and Cool Carriers, and the solidity of its parent company.

As we have seen, during the 199os the container lines' capacity surpassed that of the specialized reefer companies. Rather than being the way of carrying refrigerated cargo, the liner companies had now resurfaced as an alternative way. During this decade the discourse of "conventional reefers" took off. The independent reefer operators positioned their service, in contrast to that of the container lines, as conventional. In other words, it was not some risky innovation, it was just the service that customers had learned to trust.

We even venture to suggest that the independent reefer operators have been subjected to "container fetishism", which has been visible both in the chapters describing Cool Carriers and Seatrade. Many interviewees have expressed a disdain towards the container. Respondents frequently discuss the container's performance in and by itself, when they are actually discussing the real threat - the threat of the competition from the container lines. We would therefore venture to say that the reefer companies have centered their perceptions on the container as a representation of the large shipping lines, thereby 
condensing a larger issue on one material artifact, which would be similar to fetishism. The importance of containers for reefer operators has been discursively peripheral, even though reefer companies have been placing containers on the weather deck since the 1970s. Therefore, the reefer companies have been negating the container, positioning themselves as an alternative to container technology, rather than positioning themselves as an alternative to the container lines. With a bit of a drier approach, one could state that it is not strange that so much has been focused on the container. The very possibility of the container lines being able to compete with the reefer companies depended significantly on the technological development of the reefer container. And in the beginning, the reefer container did not deliver the service quality of a non-containerized reefer ship. It is similar to many other technological shifts, where the new technology is in the beginning inferior to the prevailing alternative ${ }^{1}$. This misperception, or at least the discourse of container fetishism, was so widespread that Mats Jansson of Cool Carriers needed to emphasise in the late 1990s that the race was not between the container and the non-containerized cargo (see chapter 5 ). It was between the independent reefer operators and the container lines. This line of reasoning was also later picked up by Seatrade when the point was to find a competitive edge for the independent reefer operators. And this could hardly be found in just being "the conventional alternative". But the discourse of the conventional reefer was spreading at the same time and even during our empirical research in 2013-2016, respondents had to stop themselves from saying the word "conventional", instead of "specialized".

In the 2000s, the container lines aggressively competed for refrigerated cargo and rapidly added container capacity. However, this negatively impacted on the independent reefer operators and resulted in a wave of consolidations.

Lauritzen acquired Cool Carriers in 2000 and merged the operations, but stated explicitly that it would not invest in tonnage. Still, many felt that this was a new beginning, something which was felt with almost every new owner of Cool Carriers. A respondent stated that "it started to feel exciting again". The upper management had several ideas for newbuilding projects but all projects were declined by Lauritzen's board. This stifled the drives of the company, since the eros and thymos could not be satisfied in the present setup. We know

1 Christensen, C. 1997. The Innovator's Dilemma: when new technologies cause great firms to fail, Boston, Mass. : Harvard Business School. 
that LauritzenCool, through Mats Jansson and others, tried to avoid container fetishism and instead started to talk about themselves as experts in refrigerated transport; the discourse shifted from reefers to logistics. Building on Lauritzen's previous success in Chile, they started a global door-to-door service called LCL, expanding vertically in the value chain, with no clear preference for shipping the refrigerated cargo in containers or not. This development can also be linked to the broader discourse of logistics that became prevalent at the same time. For LauritzenCool it was a potential solution to the contradictory sitution of being financially constrained while battling to maintain market leadership.

NYK Reefer was struggling in the end of the 1990s and decided to relocate to the core of the industry in North-Western Europe. NYK Reefer had become part of the establishment and also built up a pool of human resources that was more international, which to some extent reduced the Japaneseness of the company. When it set up NYKStar, the joint venture with Star, it was deemed important that the nature of the two companies was similar - they were both owned by traditional liner companies. However, Blue Star Line's Star Reefers was acquired by Christian Siem, who was seen by the incumbent reefer operators as a short-term speculative investor. This could be related to Siem's past as a successful investor, but also resonates with the attitudes of the independent reefer operators towards newcomers. Siem was definitively not one of the old boys. Despite that the conditions for a successful partnership had changed, both parties pressed ahead with the joint venture that became NYKStar. Siem was focused on developing his new investment which, it is claimed, caused the NYK side to take measures to ensure that they were not disadvantaged. For example, Lars Rutberg from Salén and Cool Carriers was recruited to help NYK protect their interests. The inability of the two sides to work together resulted in the joint venture being dismantled and NYK looked to LauritzenCool as a potential consolidation partner.

As a first step the relationship concerned tonnage sharing, but NYK Reefers subsequently bought $50 \%$ of LauritzenCool and LCL. The strategy for these owners was to consolidate their operations, minimise their fleets, and focus on stable contracts with major fruit companies. Therefore, the ReeferShip venture with its older ships was dismantled. This is not only connected to a rational strategy that more money can be made with modern ships. It can also be seen as thymos - the organization's drive to be the highest quality operator in the field. NYKLauritzenCool was no longer the largest independent reefer operator - Seatrade was - but strived to be perceived as the best one. NYK bought the remaining $50 \%$ in 2007 and the company was renamed NYKCool. When NYK had entered as new owners in 2004, the management saw a new chance to 
develop the business and do some newbuildings, but these desires could not be fulfilled. Similarly, they felt that they missed many good second-hand deals because of the new owners' lack of expansive ambitions. Cool Carriers which had until Lauritzen entered the scene seen themselves as autonomous was now subject to what they saw as the slow decision making of NYK. This led to the mobilization of stereotypes, both racial and cultural, about the Japanese, and about NYK in particular. At the same time, they knew that NYK had survived for more than a century, possibly because of this structure. NYK didn't allow any newbuildings, but allowed LCL to keep expanding and also approved a major financial deal with Chiquita. However, both of these businesses turned to disaster partly because of the financial crisis in 2008. As a result of these setbacks, the Japanese parent company wanted the Stockholm operation to focus on maritime reefer operations. The locus of strategy was moved away from NYKCool, and there was a significant feeling of decline in the organization. Ships were sold, people made redundant. In 2014, the company was sold to Baltic Shipping.

After the end of the relationship with NYK in 2002, Star Reefers built on their relationship to a Japanese ship-owner, which in turn had ties to a Japanese shipyard. This led to the construction of 12 state-of-the-art hybrid reefer ships - the largest investment in reefer newbuildings so far in the $21^{\text {st }}$ century. Star grew its fleet but after the economic crisis in 2008 consolidated by scrapping its older vessels. Star is proud of its modern fleet and its contracts to the major fruit companies, but its strategy is governed by logos - to be a long-term reefer tonnage provider.

Seatrade continued expanding in the 2ooos buying second-hand ships and ordering newbuildings in Japan. After a short period of turbulence, Geert Pepping emerged as the owner of Seatrade. In spring 2010 Seatrade created a pool of small vessels together with Laskaradis' Alpha Reefer pool and Green Reefers as a means to consolidate in a weak market. After a successful policy to scrap ships, the market rates improved and the two parties felt that they were better off going alone. Green Reefers continued to jointly operate with Seatrade while Laskaradis and Seatrade cut all their ties.

Seatrade has become the only remaining large independent reefer operator. They have embarked on a program of converting its reefer fleet to reefer-container vessels and are unique amongst the independent reefer operators in promoting full containerization. Seatrade have tried to convince customers to use reefer containers and promoted the quality of the reefer container. They have even constructed a meeting room in their head office out of the internal walls of a reefer container - symbolizing its focus on containerization. From the perspective of those companies now owning break-bulk reefers and still 
tied up in the discourse of container fetishism, Seatrade is moving to the dark side, educating customers in forbidden knowledge, since the message of the independent reefer companies has always been that the container is inferior to break-bulk reefers. Seatrade is thus positioning themselves as a company that offers a service different from the container lines. Casting aside container fetishism, they have returned to the original role of the independent reefer operators - providing direct maritime links with state-of-the-art technology. Its fleet renewal may also improve the company's ability to attract investment and the adoption of the dominant design of reefer shipping - container ships - increases the returns that the company could expect if it were, hypothetically, to exit the industry at some point in the future. Many wonder whether Seatrade will be able to compete, only the future can tell. 